\title{
Effect of Foliar Application of Different Chemicals on Quality of Guava (Psidium guajava L.) Var. Sardar
}

\author{
S.B. Kharwade, L.B. Surnar* and P.N. Bansod \\ College of Agriculture, Latur, Vasantrao Naik Marathwada Krishi Vidyapeeth, \\ Parbhani - 431402 (M.S.) India \\ *Corresponding author
}

\begin{tabular}{|c|}
\hline $\begin{array}{l}\text { Ke y w or d s } \\
\text { Guava, Chemicals, } \\
\text { Yield }\end{array}$ \\
\hline Article Info \\
\hline $\begin{array}{l}\text { Accepted: } \\
\text { 06 August } 2018 \\
\text { Available Online: } \\
\text { 10 September } 2018\end{array}$ \\
\hline
\end{tabular}

A B S T R A C T

The present investigation entitled "Effect of foliar application of different chemicals on quality of guava (Psidium guajava L.)" Var. Sardar was conducted in a well-established guava orchard on 9 years old Sardar guava trees planted at $6 \times 6 \mathrm{~m}$ having uniform growth and productivity at the Instructional-Cum-Research Farm, Department of Horticulture, College of Agriculture, Latur, during mrig bahar 2013-14. The experiment was laid out in Randomized Block Design (RBD) with ten treatments replicated thrice. The treatments comprised of 19:19:19@1\%( $\left.\mathrm{T}_{1}\right), 12: 61: 0 @ 1 \%\left(\mathrm{~T}_{2}\right), 0: 52: 34 @ 1 \%\left(\mathrm{~T}_{3}\right)$, Calcium Nitrate@1\% $\left(\mathrm{T}_{4}\right)$, Sulphate of Potash @ 1\% $\left(\mathrm{T}_{5}\right)$, Calcium Nitrate @ 1\% + Sulphate of Potash @1\% ( $\left.\mathrm{T}_{6}\right), \mathrm{ZnSO}_{4} @ 0.5 \%+\mathrm{FeSO}_{4} @ 0.5 \%+$ Boric acid @ 0.3\% $\left(\mathrm{T}_{7}\right), 19: 19: 19$ @1\%+2nSO $90.5 \%+\mathrm{FeSO}_{4} @ 0.5 \%+$ Boric acid @ 0.3\% $\left(\mathrm{T}_{8}\right)$, Calcium Nitrate @ $1 \%$ + Sulphate Potash + @ 1\% + $\mathrm{ZnSO}_{4} @ 0.5 \%+\mathrm{FeSO}_{4} @ 0.5 \%+$ Boric acid @ 0.3\% $\left(\mathrm{T}_{9}\right)$ and Control $\left(\mathrm{T}_{10}\right)$. The results revealed that, the maximum values of diameter of fruit $(9.17 \mathrm{~cm})$, TSS $\left(13.40{ }^{\circ}\right.$ Brix), TSS: acid ratio (34.36), acid: sugar (20.94) ratio were observed with the application of 0:52:34@1\% $\left(\mathrm{T}_{3}\right)$ and at par results were observed in Sulphate of Potash @ 1\% $\left(\mathrm{T}_{5}\right)$ treatment. The minimum per cent weight loss $(13.14 \%)$ at 8 days of storage and maximum shelf life of fruit (6.99 days) was observed in fruits obtained with the foliar application of calcium nitrate @ 1\% + Sulphate of Potash @ $1 \%+\mathrm{ZnSO}_{4}$ @ 0.5\% + $\mathrm{FeSO}_{4} @ 0.5 \%+$ Boric acid @ 0.3\% $\left(\mathrm{T}_{9}\right)$. The minimum values for most of the quality attributes studied were observed in control $\left(\mathrm{T}_{10}\right)$ treatment.

\section{Introduction}

Guava (Psidium guajava L.) "Apple of the tropics" is an important fruit crop of country. Guava is one of the fourth most important fruit crop in India after Mango, Banana and Citrus. In India, it occupies nearly 2.36 lakh hectares of area with production of 31.98 lakh metric tonnes and average productivity of 13.6 metric tonnes per hectare. In Maharashtra, it is cultivated in the area of 0.39 lakh hectare with production of 3.05 lakh metric tonnes and with an average productivity of 7.8 metric tonnes per hectare.

Low productivity of guava in Maharashtra state as compared to national, large scale use of chemical fertilizers causes the problem of ground water and environmental pollution through leaching, volatilization and 
denitrification in addition to wastage of nutrients through costly fertilizers. The disproportionate use of chemical fertilizers has widened soil imbalance in terms of NPK ratio and lowered the organic carbon contents of the soil. The occurrence of multinutrient deficiencies and overall decline in productive capacity of soil has been widely reported due to non-judicious fertilizer use (Chhonkar, 2008).

The judicious supply of nutrients not only increases the productivity but it also improves the quality of the produce. As the foliar application is an effective method of nutrient management and required nutrients can be readily supplied when they are needed. It is an effective method for correcting the micronutrient deficiencies. Hence, in recent days it has been widely practiced in high valued fruit crops like grape, mango, banana, citrus and pomegranate etc. It has been reported that the guava plant can readily absorb mineral nutrients spray or painted on the foliage. Spraying method using the correct strength have been great merit of simplicity and requires about 1 or 2 weeks to produce clear effects. Foliar application experiments conducted in India showed that guava has given good response to foliar application of different chemicals. Use of different mixed fertilizers and chemicals like calcium nitrate, magnesium sulphate, sulphate of potash, zinc sulphate, ferrous sulphate and boric acid through foliar application was found beneficial and the recommendations which have been suggested by different workers for different chemicals appears to have profound influence on fruit quality through its influence on size, appearance, colour, soluble solids, sugar, acidity and vitamin contents. Foliar application of different chemicals has increased the yield and quality parameters in guava (Arora and Singh, 1970; Ahamad et al., 1988; Ghosh, 1988; Yadav et al., 2001; Priyaawasthi, 2009; and Trivedi et al., 2012).

\section{Materials and Methods}

The present investigation entitled "Effect of foliar application of different chemicals on quality of guava (Psidium guajava L.)" Var. Sardar was carried out at College of Agriculture, Latur, during 2013-2014. The experimental site soil was medium black, slightly alkaline with uniform texture, colour and having good drainage. The experiment was conducted on well-established orchard of nine years old Sardar guava trees which are planted at $6.0 \times 6.0 \mathrm{~m}$ spacing. The experiment was laid out in Randomized Block Design (RBD) with ten treatments replicated thrice. The treatments comprised of 19:19:19 @ 1\% ( $\left.\mathrm{T}_{1}\right), 12: 61: 0 @ 1 \%\left(\mathrm{~T}_{2}\right), 0: 52: 34 @$ $1 \%\left(\mathrm{~T}_{3}\right)$, Calcium Nitrate @ 1\% $\left(\mathrm{T}_{4}\right)$, Sulphate of Potash@1\% ( $\left.\mathrm{T}_{5}\right)$, Calcium Nitrate@1\% + Sulphate of Potash@1\%( $\left.\mathrm{T}_{6}\right), \mathrm{ZnSO}_{4} @$ 0.5\%+. $\mathrm{FeSO}_{4} @ 0.5 \%+$ Boric acid@0.3\% $\left(\mathrm{T}_{7}\right), 19: 19: 19 @ 1 \%+\mathrm{ZnSO}_{4} @ 0.5 \%+$ $\mathrm{FeSO}_{4} @ 0.5 \%$ + Boric acid @ 0.3\% ( $\left.\mathrm{T}_{8}\right)$, Calcium Nitrate@1\%+Sulphate Potash + @ $1 \%+\mathrm{ZnSO}_{4} @ 0.5 \%+\mathrm{FeSO}_{4} @ 0.5 \%+$ Boric acid@0.3\% ( $\left.\mathrm{T}_{9}\right)$ and Control $\left(\mathrm{T}_{10}\right)$. Recommendations for RDF were used as 800 g N, $400 \mathrm{~g} \mathrm{P}_{2} \mathrm{O}_{5}$, and $400 \mathrm{~g} \mathrm{~K}_{2} \mathrm{O} /$ tree (Anon, 2012). After preparation of basins, FYM @ 20 $\mathrm{Kg} /$ plant was given to all trees.

\section{Results and Discussion}

An appraisal of the data presented in Table1 revealed that in the present studies, significant variation in the fruit quality parameters like length, diameter, weight of pulp, weight of seed, number of seeds and pulp: seed ratio were observed due to application of different chemicals. The data clearly showed that the treatment 12:61:0 @ 1\% $\left(\mathrm{T}_{2}\right)$ recorded maximum fruit length $(8.74 \mathrm{~cm})$ which was statistically at par with the treatment of 0:52:34@1\% $\left(\mathrm{T}_{3}\right)$, whereas, minimum fruit length $(7.06 \mathrm{~cm})$ was observed in control $\left(\mathrm{T}_{10}\right)$. 
The data revealed that the maximum diameter of the fruit $(9.17 \mathrm{~cm})$ was recorded in the treatment of 0:52:34@1\%( $\left.\mathrm{T}_{3}\right)$ which was statistically at par with 19:19:19@1\%( $\left.\mathrm{T}_{1}\right)$ and calcium nitrate @1\% $\left(\mathrm{T}_{4}\right)$, the minimum $(7.07 \mathrm{~cm})$ diameter of fruit was observed in control $\left(\mathrm{T}_{10}\right)$.

It is clear from the data that, the maximum weight of pulp $(254 \mathrm{~g})$ was recorded in the treatment of 12:61:0 @ 1\% $\left(\mathrm{T}_{2}\right)$ and the minimum (152.46 g) weight of pulp was observed in control $\left(\mathrm{T}_{10}\right)$.

It is evident from the data that, the minimum number of seeds (251.50) per fruit was recorded with the foliar application of 19:19:19@1\% $\left(\mathrm{T}_{1}\right)$ and it was statistically at par with the application of sulphate of potash @ 1\% $\left(\mathrm{T}_{5}\right)$, whereas the maximum number of seeds (346.00) per fruit were recorded in 0:52:34@1\% $\left(\mathrm{T}_{3}\right)$ treatment.

It is evident from the data that, the minimum $(3.70 \mathrm{~g})$ weight of seeds per fruit was recorded in the treatment of sulphate of potash @ $1 \%$ $\left(\mathrm{T}_{5}\right)$ and it was statistically at par with the treatments of $\mathrm{ZnSO}_{4} @ 0.5 \%+\mathrm{FeSO}_{4} @$ $0.5 \%+$ boric acid @ $0.3 \%\left(\mathrm{~T}_{7}\right)$, calcium nitrate @ 1\% $\left(\mathrm{T}_{4}\right)$, calcium nitrate @ 1\%+ sulphate of potash@1\% ( $\left.\mathrm{T}_{6}\right)$ and 19:19:19 @ 1\% $\left(\mathrm{T}_{1}\right)$

The maximum weight of seeds (6.30 g) was recorded in the treatments of 12:61:0@1\% $\left(\mathrm{T}_{2}\right)$. The highest pulp: seed ratio (57.89) was observed with the application of sulphate of potash @ 1\% $\left(\mathrm{T}_{5}\right)$. The lowest pulp: seed ratio (33.21) was observed with the application of in treatment of 19:19:19@1\%+2nSO @ @ $0.5 \%+\mathrm{FeSO}_{4} @ 0.5 \%+$ boric acid@0.3\% $\left(\mathrm{T}_{8}\right)$.

The quality improvement in terms of physical attributes of fruits with foliar application of urea has also reported by Arora and Singh (1970a). Similar findings were also reported by Rajput et al., (1986), Singh et al., (1994), Dubey et al., (2001) and Pal et al., (2008) and due to combined application of $\mathrm{N}$ and $\mathrm{P}$ by Sharma and Sharma (1992), which supports the present findings.

\section{Biochemical attributes}

The data pertaining to TSS, ascorbic acid, reducing sugar, non- reducing sugar, total sugars, acidity, TSS: acid ratio and sugar: acid ratio of guava fruits as influenced due to foliar application of different chemicals are presented in Table 2 .

The maximum TSS (13.40 ${ }^{0}$ Brix $)$ was observed with the application of 0:52:34@ $1 \%\left(\mathrm{~T}_{3}\right)$ which was statistically at par with the application of sulphate of potash @ 1\% ( $\left.\mathrm{T}_{5}\right)$, Whereas, minimum (10.45 ${ }^{0}$ Brix $)$ TSS was observed in control $\left(\mathrm{T}_{10}\right)$ treatment. The maximum (34.36) TSS: acid ratio was observed in the treatment of 0:52:34@1\% $\left(\mathrm{T}_{3}\right)$. The minimum TSS: acid ratio (19.90) was observed in $\mathrm{ZnSO}_{4} @ 0.5 \%+\mathrm{FeSO}_{4} @$ $0.5 \%$ + boric acid @ $0.3 \% \mathrm{~T}_{7}$ ) treatment.

The maximum ascorbic acid content (268.00 $\mathrm{mg} / 100 \mathrm{~g}$ ) was recorded with the application of 12:61:0@1\% ( $\left.\mathrm{T}_{2}\right)$, which was statistically at par with the application 19:19:19@1\% ( $\left.\mathrm{T}_{1}\right)$ and sulphate of potash @ 1\% ( $\left.\mathrm{T}_{5}\right)$. Whereas, the minimum (146.30 mg/100g pulp) ascorbic acid content was observed in control $\left(\mathrm{T}_{10}\right)$ treatment. Higher concentration of urea, however, had adverse effect on ascorbic acid content of fruit Dubey et al., (2001). Similar findings were also reported by Doraipandian and Shanmugrvelu (1972), Meena (2005), Rajput et al., (1986).

The maximum reducing sugars $(5.18 \%)$ was recorded with the application of sulphate of potash @ 1\% ( $\left.\mathrm{T}_{5}\right)$, while the minimum $(2.58 \%)$ reducing sugar was recorded in the control $\left(\mathrm{T}_{10}\right)$. 


\section{Int.J.Curr.Microbiol.App.Sci (2018) 7(9): 521-528}

Table.1 Effect of foliar application of different chemicals on physical attributes of guava fruits

\begin{tabular}{|c|c|c|c|c|c|c|}
\hline Treatment Details & $\begin{array}{l}\text { Fruit length } \\
\qquad(\mathrm{cm})\end{array}$ & $\begin{array}{l}\text { Fruit } \\
\text { diameter } \\
(\mathbf{c m})\end{array}$ & $\begin{array}{l}\text { Weight of } \\
\text { pulp }(g)\end{array}$ & $\begin{array}{l}\text { No. of } \\
\text { seeds/fruit } \\
\text { (g) }\end{array}$ & $\begin{array}{l}\text { Weight of } \\
\text { seed/fruit } \\
\text { (g) }\end{array}$ & $\begin{array}{l}\text { Pulp: seed } \\
\text { ratio }\end{array}$ \\
\hline $\mathrm{T}_{1^{-}}$19:19:19 @ 1\% & 8.20 & 8.48 & 226.66 & 251.50 & 4.46 & 50.82 \\
\hline 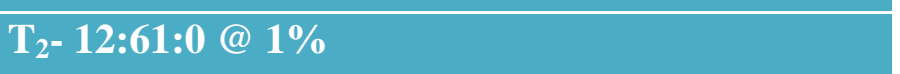 & 8.74 & 8.19 & 254.00 & 332.16 & 6.30 & 40.32 \\
\hline$T_{3^{-}}$0:52:34@1\% & 8.42 & 9.17 & 246.50 & 346.00 & 4.93 & 50.00 \\
\hline $\mathrm{T}_{4}$ - Calcium Nitrate @ 1\% & 8.37 & 8.35 & 203.00 & 314.60 & 4.40 & 46.13 \\
\hline $\mathrm{T}_{5}$-Sulphate of Potash @ 1\% & 8.15 & 8.16 & 217.66 & 268.66 & 3.70 & 57.89 \\
\hline $\begin{array}{l}T_{6-} \text { Calcium Nitrate @1\%+Sulphate of Potash } \\
@ 1 \%\end{array}$ & 8.18 & 7.72 & 221.33 & 311.36 & 4.43 & 49.96 \\
\hline $\begin{array}{l}\mathrm{T}_{7-} \mathrm{ZnSO}_{4} @ 0.5 \%+\mathrm{FeSO}_{4} @ 0.5 \%+\text { Boric acid } \\
\text { @ } 0.3 \%\end{array}$ & 7.99 & 7.64 & 164.70 & 312.00 & 4.16 & 39.60 \\
\hline $\begin{array}{l}\mathrm{T}_{8-19} \text { 19:19:19@1\%+2 } \mathrm{ZnSO}_{4} @ 0.5 \%+\mathrm{FeSO}_{4} @ \\
0.5 \%+\text { Boric acid @ 0.3\% }\end{array}$ & 8.04 & 7.66 & 179.36 & 348.13 & 5.40 & 33.21 \\
\hline $\begin{array}{l}\text { T9- Calcium Nitrate @ } 1 \%+\text { Sulphate of Potash } \\
+ \text { + } 1 \% \mathrm{ZnSO}_{4} @ 0.5 \%+\mathrm{FeSO}_{4} @ 0.5 \%+ \\
\text { Boric acid @ } 0.3 \%\end{array}$ & 8.13 & 7.74 & 200.66 & 314.33 & 4.77 & 42.06 \\
\hline $\mathrm{T}_{10^{-}}$Control. & 7.06 & 7.07 & 152.46 & 264.16 & 3.76 & 41.20 \\
\hline $\mathbf{S . E} \pm$ & 0.11 & 0.29 & 14.11 & 16.03 & 0.36 & \\
\hline C.D at $5 \%$ & 0.33 & 0.85 & 41.40 & 47.02 & 1.064 & \\
\hline
\end{tabular}


Table.2 Effect of foliar application of different chemicals on chemical composition of guava fruits

\begin{tabular}{|c|c|c|c|c|c|c|c|c|}
\hline Treatment Details & $\begin{array}{c}\text { TSS } \\
\left({ }^{0} \text { Brix }\right)\end{array}$ & $\begin{array}{l}\text { Ascorbic } \\
\text { acid } \\
\text { (mg/100g } \\
\text { fruit pulp) }\end{array}$ & $\begin{array}{l}\text { Reducing } \\
\text { sugar }(\%)\end{array}$ & $\begin{array}{l}\text { Non } \\
\text { reducing } \\
\text { sugar } \\
(\%)\end{array}$ & $\begin{array}{l}\text { Total } \\
\text { sugars } \\
(\%)\end{array}$ & $\begin{array}{l}\text { Acidity } \\
\qquad \%)\end{array}$ & $\begin{array}{l}\text { TSS/ acid } \\
\text { ratio }\end{array}$ & $\begin{array}{l}\text { Sugar/ acid } \\
\text { ratio }\end{array}$ \\
\hline $\mathrm{T}_{1}-19: 19: 19 @ 1 \%$ & 10.9 & 248.66 & 3.43 & 4.26 & 7.70 & 0.37 & 29.46 & 20.81 \\
\hline$T_{2^{-}}$12:61:0 @ 1\% & 10.71 & 268.00 & 2.65 & 4.15 & 6.71 & 0.39 & 27.47 & 15.82 \\
\hline $\mathrm{T}_{3^{-}}$0:52:34 @ 1\% & 13.40 & 166.13 & 4.49 & 3.52 & 8.17 & 0.39 & 34.36 & 20.94 \\
\hline $\mathrm{T}_{4}$ - Calcium Nitrate @ 1\% & 11.06 & $223 . .03$ & 3.61 & 4.00 & 7.84 & 0.40 & 27.65 & 19.60 \\
\hline $\mathrm{T}_{5^{-}}$Sulphate of Potash @ 1\% & 13.00 & 233.70 & 5.18 & 4.26 & 9.25 & 0.49 & 26.53 & 18.88 \\
\hline $\begin{array}{l}\text { T6- Calcium Nitrate @1\% + Sulphate of } \\
\text { Potash @ 1\% }\end{array}$ & 10.53 & 153.00 & 4.53 & 2.55 & 7.08 & 0.47 & 22.40 & 15.06 \\
\hline $\begin{array}{l}\mathrm{T}_{7^{-}} \mathrm{ZnSO}_{4} @ 0.5 \%+\mathrm{FeSO}_{4} @ 0.5 \%+ \\
\text { Boric acid @ } 0.3 \%\end{array}$ & 10.94 & 176.33 & 4.39 & 4.19 & 7.98 & 0.55 & 19.90 & 14.50 \\
\hline $\begin{array}{l}\mathrm{T}_{8^{-}} 19: 19: 19 @ 1 \%+\mathrm{ZnSO}_{4} @ 0.5 \%+ \\
\mathrm{FeSO}_{4} @ 0.5 \% \text { + Boric acid @ 0.3\% }\end{array}$ & 10.45 & 146.33 & 4.62 & 2.63 & 8.90 & 0.52 & 20.95 & 17.11 \\
\hline $\begin{array}{l}\text { T9- Calcium Nitrate @ 1\% + Sulphate of } \\
\text { Potash @ } 1 \%+\mathrm{ZnSO}_{4} @ 0.5 \%+ \\
\mathrm{FeSO}_{4} @ 0.5 \%+\text { Boric acid @ } 0.3 \%\end{array}$ & 11.00 & 193.30 & 4.41 & 4.40 & 8.00 & 0.54 & 20.37 & 14.81 \\
\hline $\mathrm{T}_{10^{-}}$Control. & 10.45 & 146.30 & 2.58 & 3.63 & 6.02 & 0.47 & 22.40 & 12.80 \\
\hline S.E \pm & 0.14 & 12.22 & 0.06 & 0.15 & 0.22 & 0.017 & & \\
\hline C.D at $5 \%$ & 0.42 & 35.86 & 0.20 & 0.45 & 0.66 & 0.052 & & \\
\hline
\end{tabular}


Table.3 Effect of foliar application of different chemicals on physiological loss in weight (PLW) and shelf life of guava fruits

\begin{tabular}{|c|c|c|c|c|c|c|}
\hline \multirow[t]{2}{*}{ Treatments } & \multirow{2}{*}{$\begin{array}{c}\text { Initial } \\
\text { weight }(g)\end{array}$} & \multicolumn{4}{|c|}{ Physiological loss in weight (\%) } & \multirow{2}{*}{$\begin{array}{l}\text { Shelf life } \\
\text { (days) }\end{array}$} \\
\hline & & After 2 days & After 4 days & After 6 days & After 8 days & \\
\hline$T_{1-}$ 19:19:19@1\% & 993 & $\begin{array}{c}4.28 \\
(950)\end{array}$ & $\begin{array}{c}8.31 \\
(910)\end{array}$ & $\begin{array}{l}13.18 \\
(861)\end{array}$ & $\begin{array}{l}16.30 \\
(830)\end{array}$ & 5.37 \\
\hline $\mathrm{T}_{2-12: 61: 0 @ 1 \%}$ & 1315 & $\begin{array}{c}2.36 \\
(1283)\end{array}$ & $\begin{array}{c}4.66 \\
(1253)\end{array}$ & $\begin{array}{c}7.23 \\
(1220)\end{array}$ & $\begin{array}{c}14.24 \\
(1146)\end{array}$ & 6.66 \\
\hline T3- 0:52:34@1\% & 1225 & $\begin{array}{c}3.10 \\
(1186)\end{array}$ & $\begin{array}{c}6.35 \\
(1146)\end{array}$ & $\begin{array}{c}9.89 \\
(1103)\end{array}$ & $\begin{array}{c}14.51 \\
(1035)\end{array}$ & 6.33 \\
\hline T/4 - Calcium Nitrate@ 1\% & 1033 & $\begin{array}{c}3.58 \\
(996)\end{array}$ & $\begin{array}{l}9.03 \\
(940)\end{array}$ & $\begin{array}{l}12.92 \\
(900)\end{array}$ & $\begin{array}{l}16.19 \\
(866)\end{array}$ & 5.66 \\
\hline T5-Sulphate of Potash @ 1\% & 1056 & $\begin{array}{c}4.53 \\
(1008)\end{array}$ & $\begin{array}{c}7.55 \\
(976)\end{array}$ & $\begin{array}{l}10.09 \\
(950)\end{array}$ & $\begin{array}{l}15.44 \\
(893)\end{array}$ & 5.66 \\
\hline $\begin{array}{l}T_{6^{-}} \text {Calcium Nitrate @ 1\%+Sulphate of } \\
\text { Potash@ } 1 \%\end{array}$ & 1135 & $\begin{array}{c}5.92 \\
(1065)\end{array}$ & $\begin{array}{c}9.48 \\
(1025)\end{array}$ & $\begin{array}{l}12.00 \\
(1006)\end{array}$ & $\begin{array}{l}14.09 \\
(973)\end{array}$ & 6.33 \\
\hline $\begin{array}{l}\mathrm{T}_{7-} \mathrm{ZnSO}_{4} @ 0.5 \%+\mathrm{FeSO}_{4} @ 0.5 \%+ \\
\text { Boric acid @ 0.3\% }\end{array}$ & 865 & $\begin{array}{c}6.71 \\
(805.33)\end{array}$ & $\begin{array}{l}10.45 \\
(773)\end{array}$ & $\begin{array}{l}13.14 \\
(750)\end{array}$ & $\begin{array}{l}16.21 \\
(723)\end{array}$ & 5.66 \\
\hline $\begin{array}{l}\mathrm{T}_{8-19:} 19: 19 @ 1 \%+\mathrm{ZnSO}_{4} @ 0.5 \%+ \\
\mathrm{FeSO}_{4} @ 0.5 \%+\text { + Boric acid @ } 0.3 \% .\end{array}$ & 901 & $\begin{array}{l}3.60 \\
(868)\end{array}$ & $\begin{array}{l}6.51 \\
(84)\end{array}$ & $\begin{array}{l}9.94 \\
(810)\end{array}$ & $\begin{array}{l}13.18 \\
(780)\end{array}$ & 5.66 \\
\hline $\begin{array}{l}\text { T9- Calcium Nitrate@1\% + Sulphate of } \\
\text { Potash+@ @ } 1 \% \mathrm{ZnSO}_{4} @ 0.5 \%+\mathrm{FeSO}_{4} @ \\
0.5 \% \text { + Boric acid @ } 0.3 \%\end{array}$ & 1053 & $\begin{array}{c}4.04 \\
(1010)\end{array}$ & $\begin{array}{l}7.05 \\
(976)\end{array}$ & $\begin{array}{l}10.43 \\
(940)\end{array}$ & $\begin{array}{l}13.14 \\
(910)\end{array}$ & 6.99 \\
\hline $\mathrm{T}_{10^{-}}$Control. & 780 & $\begin{array}{l}6.98 \\
(723)\end{array}$ & $\begin{array}{l}12.50 \\
(683)\end{array}$ & $\begin{array}{l}16.41 \\
(650)\end{array}$ & $\begin{array}{l}22.16 \\
(603)\end{array}$ & 4.33 \\
\hline $\mathrm{SE} \pm$ & 38.07 & 1.14 & 1.55 & 1.64 & 1.85 & 0.43 \\
\hline C.D at $5 \%$ & 113.11 & 3.39 & 4.60 & 4.88 & 5.50 & 1.29 \\
\hline
\end{tabular}


The maximum $(4.40 \%)$ non reducing sugar were recorded in the treatment of Calcium Nitrate@1\% + Sulphate of Potash @ 1\% + $\mathrm{ZnSO}_{4} @ 0.5 \%+\mathrm{FeSO}_{4} @ 0.5 \%+$ Boric acid @ $0.3 \%\left(\mathrm{~T}_{9}\right)$. and it was statistically at par with the application of 19:19:19 @ $1 \% \quad\left(\mathrm{~T}_{1}\right)$, Sulphate of Potash@1\% ( $\left.\mathrm{T}_{5}\right), 12: 61: 0 @ 1 \%$ $\left(\mathrm{T}_{2}\right)$ and calcium nitrate @ $1 \%\left(\mathrm{~T}_{4}\right)$. The minimum $(2.55 \%)$ non reducing sugar contents were recorded with the application of calcium nitrate@1\%+ sulphate of potash @ 1\% $\left(\mathrm{T}_{6}\right)$.

The maximum $(9.25 \%)$ total sugar was recorded in the treatment of sulphate of potash @ $1 \%\left(\mathrm{~T}_{5}\right)$ which was statistically at par with 19:19:19@1\%+2nSO $@$ @ 0.5\% + $\mathrm{FeSO}_{4} @$ $0.5 \%+$ Boric acid @ 0.3\% $\left(\mathrm{T}_{8}\right)$ while, the minimum $(6.537 \%)$ total sugar content was observed in control $\left(\mathrm{T}_{10}\right)$ treatment.

The increased in non-reducing sugar and total sugar with potassium compounds alone or in combination with other nutrients may be due to increased rate of photosynthesis which accumulated more sugars in fruits.

Similar results with potassium application compound have also been reported by Singh et al., (1981), which support the result of present investigation.

The data showed that, the minimum $(0.37 \%)$ acidity was recorded in the treatment of 19:19:19@1\% $\left(\mathrm{T}_{1}\right)$ and it was statistically at par with the 12:61:0@1\% $\left(\mathrm{T}_{2}\right), 0: 52: 34 @ 1 \%$ $\left(\mathrm{T}_{3}\right)$ and Calcium Nitrate @ 1\% $\left(\mathrm{T}_{4}\right)$. Whereas, the maximum $(0.55 \%)$ acidity was recorded in $\mathrm{ZnSO}_{4} @ 0.5 \%+\mathrm{FeSO}_{4} @ 0.5 \%+$ Boric acid @ $0.3 \%\left(\mathrm{~T}_{7}\right)$ treatment.

The maximum sugar: acid ratio (20.94) was observed in the treatment of 0:52:34@1\% $\left(\mathrm{T}_{3}\right)$, while the minimum (12.80) TSS: acid ratio was observed in control $\left(\mathrm{T}_{10}\right)$ treatment

\section{Post-harvest quality}

The minimum physiological weight loss $(13.14 \%)$ after 8 days storage and maximum shelf life (6.99 days) was recorded in fruits produced from the foliar application of Calcium Nitrate@1\%+Sulphate of Potash@1\%+ $\mathrm{ZnSO}_{4} @ 0.5 \%+\mathrm{FeSO}_{4} @ 0.5 \%+$ Boric acid @ $0.3 \%\left(\mathrm{~T}_{9}\right)$. Similar findings were also reported by Kumar et al., (2011) (Table 3).

He reported that the reduction in weight loss of guava fruits with foliar application of $\mathrm{GA}_{3}$ and borax. Mandal et al., (2010) also reported that the foliar application of $1 \%$ calcium nitrate in guava effectively reduced the spoilage, maintained higher firmness, TSS and ascorbic acid up to 2 days.

The minimum PLW (\%) and prolonged shelf life of guava fruits was observed due to foliar application of $0.4 \% \mathrm{ZnSO}_{4}$ (Goswami et al., 2012).

The Foliar application of different chemicals was found beneficial for increasing quality of guava. The application of potash alone (Sulphate of Potash)@1\% or in combination with other nutrients like Calcium Nitrate $\left(\mathrm{T}_{6}\right)$ or micronutrients $\left(\mathrm{T}_{9}\right)$ produced beneficial effects on quality attributes of guava fruits. The overall performance of application of Calcium Nitrate + Sulphate of Potash each @ 1\% ( $\left.\mathrm{T}_{6}\right)$ was found superior and it was closely followed with the application of $19: 19: 19 @ 1 \%+\mathrm{ZnSO}_{4}+$ $\mathrm{FeSO}_{4}$ each@0.5\% + Boric acid @0.3\% $\left(\mathrm{T}_{8}\right)$ for improving quality from guava.

Thus, it can be concluded that two foliar sprays of Calcium Nitrate plus Sulphate of Potash each @ 1\% or 19:19:19@1\%+2nSO $+\mathrm{FeSO}_{4}$ each@0.5\%+Boric acid @ 0.3\% at 30 and 60 days after flowering will be beneficial for increasing the quality of guava under Marathwada conditions.

\section{References}

Ahamad, M.D.F., Shankar, G. and Sharma, R.R. 1998a. Yield and quality parameters of guava as influenced by foliar application of ferrous sulfate. Ann. of Agric. Res., 19(2): 196-198. 
Anonymous. 2013. Indian Horticulture Database, National Horticulture Board, Government of India.

Arora, J.S. and Singh, J.R. 1970a. Effect of nitrogen, phosphorus and potassium spray on guava (Psidium guava L.). J. Jap. Soc. Hort. Sci., 39(1): 55-62.

Chhonkar, P.K. 2008. Organic farming and its relevance in India. Organic agriculture. Indian Society of Soli Science, Jodhpur. pp: 5-33

Dabey, A.K., Singh, D.B. and Neeru D. 2001. Effect of foliar spray of urea on fruit yield and quality of guava (Psidium guajava L.) Prog. Hort. 33(1): 37-40.

Doraipandian, A. and shanmugavelu, K.G. 1972. Effect of foliar spray of urea on the yield of guava. South Indian Hort., 20: 80-81.

Ghosh, S.N. 1986. Effect of magnesium, zinc and manganese on yield and fruit quality of guava. South Indian Hort. 34(5): 327330.

Goswami, A.K., Shukla, H.S., Kumar, P. and Mishard, D.S. 2012. Effect of pre-harvest application of micro-nutrients on quality of guava (Psidium guajava L.) $\mathrm{Cv}$. Sardar. HortFlora. Research. Spectrum, 1(1): 60-63.

Kumar, S., Singh, A.K. and Singh, A. 2011. Effect of foliar application of various growth regulators nutrients on shelf life and chemical attributes of guava $\mathrm{Cv}$. Plant Archives, 11(1): 107-111.

Mandal, G., Dhaliwal, H.S. and Mahajan, B.V.C. 2010. Effect of pre-harvest calcium sprays on post-harvest life of winter guava (Psidium guajava L.) Journal of Food Science and Technology, 47(5): 501-506.

Meena, R.P., Mohammed, S. and Lakhawat, S.S. 2005. Effect of foliar application of urea and zinc sulphate on fruit quality and yield of pruned guava tree (Pisidium guajava L.) Cv. Sardar under high density planting system. Journal of Horticulture science, 11(2): 90-93.

Pal, A., Pathak, R.K., Pal, K. and Singh, T. 2008. Effect of foliar application of nutrients on yield and quality of guava (Psidium guajava L.) fruit Cv. Sardar. Progressive Research, . 3(1): 89-90.

Priyaawasthi and Shantlal. 2009. Effect of calcium, boron and zinc foliar sprays on the yield and quality of guava (Psidium guajava L.) Pantnagar Journal of Research 7(2): 223-224.

Rajput, C.B.S., Singh, N.P. and Tiwari, J.P. 1978. Effect of potash on yield attributes of guava (Psidium guajava L.). Indian J. Hort., 35: 19-22

Sharma, D.P. and Sharma, R.G. 1992. Effect of foliar application of $\mathrm{N}-\mathrm{P}-\mathrm{K}$ on growth and yield of guava (Psidium guajava L.) Advances in plant sciences, 5: 313-315.

Singh, H.K. Singh, B.P. and Chauhan, K.S. 1981. Effect of foliar feeding of various chemicals on physico-chemical quality of guava fruits. Haryana agric.res., 11(3): 411-414.

Trivedi, N., Singh, D., Bhadur, V., Prasad, V.M. and Collis, J.P. 2012. Effect of foliar application of zinc and boron on yield and quality of guava (Psidium guajava L.). Hort. flora Research Spectrum, 1(3):281-283.

Yadav, H.C., Yadav, A.L., Yadav, D.K. and Yadav, P.K. 2011. Effect of foliar application of micronutrients and $\mathrm{GA}_{3}$ on fruit yield and quality of rainy season guava (Psidium guajava L.) Cv. L-49 Plant Archives, 11: 147-149.

\section{How to cite this article:}

Kharwade, S.B., L.B. Surnar and Bansod, P.N. 2018. Effect of Foliar Application of Different Chemicals on Quality of Guava (Psidium guajava L.) Var. Sardar. Int.J.Curr.Microbiol.App.Sci. 7(09): 521-528. doi: https://doi.org/10.20546/ijcmas.2018.709.062 